\title{
Diagnoza funkcjonalno-przestrzenna krakowskich osiedli mieszkaniowych Olsza II i Ugorek jako wynik współpracy uczelnia - samorząd
}

\section{Spatial and functional diagnosis of Krakow housing developments - Olsza II and Ugorek, as a result of the university and local authority cooperation}

\section{Streszczenie}

Współpraca między uczelnią, samorządem a biznesem wyznacza nowe i przyjęte wcześniej kierunki rozwoju szkół wyższych, dla których porozumienia między jednostkami branżowymi o różnym charakterze według władz miasta mieszczą się w ich strategii rozwoju. W artykule zaprezentowane zostały główne założenia projektu realizowanego przez wyznaczony zespół Katedry Kształtowania Środowiska Mieszkaniowego Instytutu Projektowania Urbanistycznego Wydziału Architektury Politechniki Krakowskiej w porozumieniu z Instytutem Socjologii Uniwersytetu Jagiellońskiego na zlecenie Urzędu Miasta Krakowa. Interdyscyplinarny charakter badań pozwala na zdobycie szerokiego spojrzenia na zagadnienia podejmowane w projekcie w oparciu o wiedzę i doświadczenia ekspertów różnych dziedzin.

Słowa kluczowe: projekt naukowy, diagnoza funkcjonalno-przestrzenna, jednostki eksperckie

Abstract

The cooperation between the University, local authority and business sets new and already established directions for the development of the higher education institutions. The agreements between various business units and the city authorities are included in the universities' development strategies. The paper presents the main assumptions of the project commissioned by the Cracow Municipal Office and implemented by the designated team of the Chair of Housing Environment, Institute of Urban Design, Faculty of Architecture, Cracow University of Technology, in cooperation with the Institute of Sociology of the Jagiellonian University. In addition, the interdisciplinary character of the research allows us to gain a broad insight into the issues undertaken in the compliance with the knowledge and experience of experts in various fields.

Keywords: scientific project, spatial-functional diagnosis, expert units 


\section{DLACZEGO WSPÓŁPRACA MIĘDZY UCZELNIĄ, SAMORZĄDEM I JEDNOSTKAMI BIZNESU JEST WAŻNA?}

Wizerunek uczelni zmienia się, tak jak zmieniają się wymagania kierowane w stronę szkół wyższych. Choć wciąż niezwykle ważny jest poziom kształcenia, jak i działalność naukowa, które mają podstawowe znaczenie dla przyszłości uczelni. Badania naukowe, w tym projekty, w ramach których są realizowane, mogą wynikać ze współpracy z biznesem czy też samorządami. Porozumienia te niosą duże korzyści dla jednostek samorządowych, biznesowych, jak i uczelni. Możliwość wyjścia szerzej z działalnością naukową pozwala na promowanie jej efektów i zastosowanie wyników w praktyce. Tematyka podejmowanych wspólnie działań ma na celu przynieść między innymi korzyści społeczne, wynikające z podniesienia standardów życia.

Jednym z najistotniejszych działań zaplanowanych w dokumentach strategii uczelni jest utrzymanie i rozwijanie współpracy z samorządami zarówno w zakresie dydaktyki, jak i nauki. W ramach aktywności dydaktycznej porozumienia dotyczą najczęściej udziału studentów w projektach stanowiących opracowania ofertowe dla wskazanych przez urzędy miast lokalizacji. Student ma okazję projektować w realnych lokalizacjach, uwzględniając istotne i prawdziwe uwarunkowania, czasem wprowadzające wiele ograniczeń. Urzędy miast mają natomiast do dyspozycji, stworzone najczęściej przez dyplomantów, oferty obrazujące potencjał terenu oraz możliwości jego zagospodarowania. Dla studentów aktywność ta stanowi cenny element w pozyskiwaniu doświadczenia w zawodzie, często już wymaganego na etapie poszukiwania pracy przez absolwentów uczelni.

Przykładem efektywnej współpracy uczelni z biznesem są niejednokrotnie funkcjonujące współczesne parki technologiczne. Na ogół prężnie rozwijają się z uwagi na zaplecze naukowe, jak i możliwości, jakie stwarzają firmy branżowe, postrzegane jako jednostki biznesu. Wprowadzając nowy produkt, mają szansę wcześniejszego przebadania go, udoskonalania, co zapewniają ośrodki nauki. Laboratoria uczelni podejmujące badania w zakresie konkretnych obszarów swej działalności, prowadzą doświadczenia, analizy, projekty naukowe przy współpracy z ekspertami danej dziedziny, praktykami, naukowcami, przedstawicielami biznesu i władz, dążąc do realizacji wspólnych celów. W zależności od dziedziny, w której wyspecjalizowane są laboratoria, oferty badawcze kierowane są do producentów określonych produktów, materiałów budowlanych, projektantów, deweloperów czy też prywatnych inwestorów.

Prowadzenie badań ma sens, którym jest możliwość wykorzystania ich efektów w praktyce. Świadczy to o ich przydatności. Tego typu badania nie tylko pozostają ważne dla nauki, ale także mają swe zastosowanie. Tematyka badań wymaga niejednokrotnie kompleksowego spojrzenia, które możliwe jest przy wykorzystaniu wiedzy z zakresu wielu dyscyplin naukowych, co wymaga współpracy także między uczelniami o różnym profilu naukowym. Interdyscyplinarność badań stwarza szansę na szerszą analizę podejmowanego problemu badawczego. 
Osobnym problemem są wymagania określone dla partnerów decydujących się na udział w projektach naukowych, w których uczelnia nie może być składającym wnioski, a jedynie partnerem. Stanowi to duże ograniczenie. Tym bardziej ogromne znaczenie ma ścisła współpraca z firmami branżowymi i jednostkami samorządowymi, bowiem dana jednostka uczelni może zostać zaproszona do udziału w projekcie naukowym jako partner bądź nie. Ośrodek nauki przy realizacji wspólnie podejmowanych działań z biznesem stwarza możliwość wykorzystania jego potencjału, doświadczenia, wiedzy i aparatury badawczej, do której obsługi konieczna jest wyspecjalizowana kadra. Omawiana współpraca jest ważna, a właściwie konieczna w zakresie dziedzin nowych, wymagających analizy, badań, dogłębnego poznania. Innym rodzajem badań naukowych są projekty realizowane na zlecenie samorządów, powstające w oparciu o zasady partycypacji społecznej. Dla ich przebiegu istotne znaczenie ma opinia osób zainteresowanych i użytkowników.

\section{GŁÓWNE ZAŁOŻENIA PROJEKTU „DIAGNOZA FUNKCJONALNO-PRZESTRZENNA OSIEDLI: OLSZA II I UGOREK"}

Projekt naukowy „Diagnoza funkcjonalno-przestrzenna osiedli: Olsza II i Ugorek” stanowił fragment większego pilotażowego programu rehabilitacji zabudowy blokowej na terenie gminy Kraków, który był realizowany przez cztery lata od 2010 roku. Podstawą prac nad programem rehabilitacji była podjęta przez Radę Miasta Krakowa uchwała z dnia 12 maja 2010 roku w sprawie kierunków działania dla Prezydenta Miasta Krakowa w zakresie przygotowania programu rehabilitacji zabudowy blokowej osiedli na terenie Gminy Kraków (uchwała nr c/1346/10) oraz umowa zawarta przez Instytut z Urzędem Miasta Krakowa, reprezentowanym przez Wydział Strategii i Rozwoju Miasta.

W projekcie odnoszono się do zagadnienia procesu rehabilitacji, rozumianego jako jeden z etapów rewitalizacji fragmentów miasta. Tak interpretowany problem wymagał szerszego spojrzenia zarówno w zakresie zagadnień społecznych, ekonomicznych, jak i środowiskowych. Istotnym wsparciem dla formułowania założeń programu rehabilitacji osiedli zabudowy blokowej były już zrealizowane opracowania - Miejski Program Rewitalizacji Krakowa oraz związane z nim Lokalne Programy Rewitalizacji dla wybranych obszarów miasta Krakowa. Celem programu było ustalenie głównych problemów towarzyszących wyznaczonym do badań obszarom oraz wyznaczenie kierunków działań, zmierzających do poprawy jakości życia mieszkańców, poprawy komfortu ich środowiska zamieszkania.

Ponieważ program powstawał w oparciu o zasady partycypacji społecznej, wymagał aktywności partnerów projektu w czasie organizowanych warsztatów, wspólnych dyskusji, wykładów oraz konsultacji społecznych.

Jednym z postulatów współczesnych tendencji w zakresie kształtowania środowiska mieszkaniowego wysokiej jakości są zasady zrównoważonego rozwoju miast, o których 
między innymi mówi „Nowa Karta Ateńska. Wizja Miast XXI wieku” Europejskiej Rady Urbanistów czy też „Karta Lipska na rzecz zrównoważonego rozwoju miast europejskich”. Dokumenty te interpretują zrównoważone środowisko mieszkaniowe jako zdrowe i przyjazne człowiekowi miejsce do życia, w którym priorytetem jest człowiek i jego potrzeby. Takie obszary powinny być wygodne, bezpieczne, umożliwiające realizację preferowanego przez społeczność stylu życia.

W projekcie dotyczącym „Diagnozy funkcjonalno-przestrzennej osiedli: Olsza II i Ugorek” udział wzięli: Politechnika Krakowska, Wydział Architektury, Instytut Projektowania Urbanistycznego, Katedra Kształtowania Środowiska Mieszkaniowego, Instytut Socjologii Uniwersytetu Jagiellońskiego, Stowarzyszenie Pracownia Obywatelska, Wydział Rozwoju Miasta Urzędu Miasta Krakowa. Partnerzy reprezentowali różne dyscypliny nauki, jak i jednostkę samorządową, dzięki czemu możliwe było zgłębienie problemu w zakresie różnych obszarów wiedzy doświadczeń. Ocena jakości obszarów mieszkaniowych, a ściślej sąsiedztw wyznaczonych w ramach osiedli Olsza II i Ugorek, wymagała analizy trzech grup problemowych. Pierwsza grupa dotykała zagadnień związanych z jakością środowiska mieszkaniowego. Jest to obszar problemowy niezwykle rozległy i trudny do zdefiniowania, począwszy od określenia skali, w jakiej prowadzone są rozważania, ustalenia zakresu i wyznaczenia elementów poddanych późniejszym badaniom, co wynika z subiektywnych odczuć - indywidualnych preferencji. Nie jest bowiem możliwe jednoznaczne zdefiniowanie środowiska mieszkaniowego wysokiej jakości. Dla każdego komfort może oznaczać coś innego, bowiem upodobania i preferencje jednostek względem miejsca zamieszkania mogą być różne.

Druga grupa problemowa dotyczy specyfiki wybranych krakowskich osiedli. Ich wielkości, cech charakterystycznych związanych choćby z typologią zabudowy, infrastrukturą oraz systemem zieleni, siecią usług itd. W przypadku Olszy II i Ugorka znaczenie ma lokalizacja - bliskość centrum miasta i system powiązań osiedli z innymi dzielnicami Krakowa. Trzecia grupa problemowa dotyczyła stworzenia metody badań na podstawie analizy urbanistycznej, której wyniki, a następnie wnioski uzupełnione zostały o opinię mieszkańców, którzy z obszarem poddanym analizom czują się związani najmocniej. Aspekt społeczny miał więc ogromne znaczenie w każdym z wyznaczonych obszarów. Opinia mieszkańców była pomocna w wyznaczeniu kierunków działań na rzecz poprawy jakości środowiska mieszkaniowego. Nie mogła być jednak jedynym kierunkiem działań, zwłaszcza że nie mogła zastąpić wiedzy grupy architektów, socjologów czy też zespołu reprezentującego Urząd Miasta Krakowa.

Sami mieszkańcy - należy o tym także pamiętać - prezentowali opinie subiektywne z uwagi na ich zaangażowanie emocjonalne, naturalne w przypadku środowiska mieszkaniowego, z którym czują się związani. Bowiem środowisko mieszkaniowe kojarzone jest z domem bliskim każdemu człowiekowi. Przywołuje on nie tylko wrażenia wizualne wyrażone przez architekturę, ale przede wszystkim duchowe związane $z$ indywidualnymi emocjami, w tym przywiązaniem do swojego domu - miejsca zamieszkania, z którym każdy z nas się utożsamia. Ocena komfortu miejsca zamieszkania jest także w dużym stopniu 
niewymierna, zwłaszcza gdy dotyczy osobistych odczuć - trudno zmierzyć przy ocenie wartości estetyczne miejsca. Dokonać oceny, czy analizowany obszar jest ładny, czy brzyd$\mathrm{ki}$ - to ocena subiektywna.

Przy ocenie osiedli wprowadzono trzy grupy zagadnień, charakteryzujących w prosty sposób środowisko mieszkaniowe akceptowane, a nawet pożądane przez mieszkańców. Jest to osiedle: „żyjące”, wygodne i zdrowe. Osiedle żyjące zinterpretowane zostało jako osiedle zapewniające aktywność mieszkańców, życie, które nie sprowadza się do użytkowania środowiska mieszkaniowego jako sypialni, ale miejsca, w którym można realizować wiele aktywności. Aby spełnić ten warunek, ważny jest odpowiedni program usług z miejscami różnego rodzaju aktywności, zapewnionych przez miejsca rekreacji o charakterze biernym i czynnym oraz miejsca spotkań, które mieszkańcy lubią i z którymi chcą się identyfikować.

Osiedle wygodne przez swój układ funkcjonalno-przestrzenny powinno zapewniać wygodę w użytkowaniu przestrzeni, w tym łatwą dostępność do usług przez sprawny system komunikacji pieszej, rowerowej i zbiorowej, czy też indywidualnej, jak i czytelność rozwiązań przestrzennych z uwzględnieniem akcentów stanowiących zapamiętywane znaki przestrzenne. Rozpoznawalne i zapamiętywane, przez co kojarzone z danym miejscem. Przez określenie osiedle zdrowe rozumie się obszar zamieszkania sprzyjający zdrowiu psychofizycznemu człowieka. Sprzyjają temu przestrzenie i obiekty o charakterze sportowym i rekreacyjnym, zapewniające aktywność ruchową osób będących w różnym wieku. Na samopoczucie psychiczne pozytywnie oddziałują elementy przyrodnicze, przy czym bardzo ważna jest ich bliskość. Poczucie spójności społecznej wzmacniane jest przez istnienie i odpowiedni sposób zagospodarowania przestrzeni wspólnych. Należy jednak wziąć pod uwagę, że potrzeby jednostek często są sprzeczne względem siebie.

„Żyjemy w ciągłym rozdarciu pomiędzy rywalizującymi ze sobą potrzebami. Trudno zaś o impulsy bardziej sprzeczne niż zaangażowane w nieustanną przepychankę. Potrzeba odosobnienia z jednej i bliskiego kontaktu z innymi ludźmi z drugiej strony. Jak widać, pod pewnymi względami nasze pragnienia toczą ze sobą prawdziwe wojny. Potrzeba nam ożywczego i pomocnego ciepła innych osób, lecz także uzdrawiającego dotyku natury. Chcemy tworzyć więzi z ludźmi, lecz zarazem musimy czasem od nich się oddalić. Korzystamy z wygód i udogodnień, jakie niesie ze sobą bliskość innych istot ludzkich, lecz bywa, że ceną, jaką przychodzi nam za to zapłacić, jest nadmiar bodźców i poczucie stłoczenia” ${ }^{1}$.

Podane warunki stały się tematem badań. Skupiają się one wokół nowych tendencji podyktowanych przez zasady rozwoju zrównoważonego, w tym promowania prozdrowotnych warunków życia. Dla ich podtrzymywania istotne znaczenie mają: wielkości fizyczne związane z odległościami i proporcjami (o czym w dużej mierze decyduje przyjazna skala, dystans między obiektami), wrażenia wizualne związane z walorami estetycznymi, charakterem przestrzeni, ich czytelnością oraz elementy kształtujące poczucie intymności i spokoju oraz bezpieczeństwa. Są to w opinii mieszkańców jedne z najważniejszych elementów kształtujących 
przyjazne człowiekowi środowisko. Dziś każdy z nas potrzebuje miejsc cichych, w których można odpocząć i nabrać sił. Często miejscami tymi są przestrzenie zielone.

Jako podstawowy cel badań przyjęto sporządzenie diagnozy stanu istniejącego. Na podstawie wyników analizy sformułowane zostały wnioski przydatne do procesu rewitalizacji wskazanych osiedli (Olsza II i Ugorek), z uwzględnieniem atutów, a z drugiej strony problemów osiedli ze wskazaniem środków zaradczych - propozycji zmian dla poprawy warunków środowiska mieszkaniowego.

\section{PODSUMOWANIE}

Współpraca między uczelniami, samorządami i biznesem jest ważna dla każdego z wymienionych sektorów. Ma ona różny charakter w zależności od celowości podjętych działań. Niekiedy opiera się na efektach procesu dydaktycznego, wówczas są to proponowane przez studentów projekty, prezentowane jako opracowania ofertowe, możliwe do wykorzystania w przyszłości. Korzyścią dla prywatnych inwestorów, deweloperów czy po prostu samorządów jest powstała koncepcja projektowa, uwzględniająca mocne strony terenu przeznaczonego pod inwestycję. Jest ona dostosowana do warunków podyktowanych przez studium uwarunkowań i kierunków zagospodarowania przestrzennego, przy uwzględnieniu wszelkich ograniczeń nałożonych na konkretną lokalizację.

Dla studentów korzyścią jest możliwość projektowania w realnej lokalizacji, co stanowi przygotowanie do pracy w zawodzie, gdzie wymagana jest praca projektowa daleka od abstrakcyjnych koncepcji, nie mających bezpośredniego przełożenia na realne opracowania dotyczące konkretnych obszarów.

Szczególnie cenne są opracowania naukowe przy udziale jednostek samorządowych, biznesu i uczelni, które pozwalają na wdrożenie badań naukowych, a więc wykorzystanie ich wyników w praktyce.

Badania, jeśli nie dotyczą badań konkretnych produktów, takich jak np. materiały budowlane, bardzo często związane są z szerszym zakresem problemowym, jak na przykład energooszczędne budownictwo, proekologiczna architektura, wykorzystująca uwarunkowania klimatyczne itd. Tego typu problemy o charakterze interdyscyplinarnym wymagają wykorzystania wiedzy i doświadczeń ekspertów oraz praktyków z różnych dziedzin nauki.

W ostatnich latach wyznaczony zespół Katedry Kształtowania Środowiska Mieszkaniowego ${ }^{2}$ we współpracy z naukowcami z Instytutu Socjologii Uniwersytetu Jagiellońskiego oraz Urzędem Miasta Krakowa podjął badania dotyczące rehabilitacji zabudowy blokowej na terenie gminy Kraków. Wyznaczono sąsiedztwa - mniejsze obszary w ramach dwóch krakowskich osiedli - Olsza II i Ugorek, dokonując oceny stanu zagospodarowania przestrzeni osiedli. Analizy pozwoliły na wyłonienie mocnych i słabych stron terenu ze wskazaniem kierunków działań zmierzających do poprawy jakości rozpatrywanych osiedli, z uwzględnieniem zasad 
wyznaczonych przez idee zrównoważonych jednostek mieszkaniowych, dla których priorytetem jest użytkownik - jego potrzeby oraz wymagania skoncentrowane wokół zdrowego stylu życia, zapewniającego prawidłową kondycję psychofizyczną mieszkańców.

Projekt powstawał w oparciu o zasady partycypacji społecznej, co wymagało organizacji spotkań, warsztatów, wykładów dla mieszkańców. Wydarzenia te były okazją do wysłuchania i uwzględniania opinii mieszkańców na temat prowadzonych badań, na temat ich środowiska mieszkaniowego. Z natury subiektywna opinia mieszkańców wynikała w dużej mierze z przywiązania do terenu, z którym mieszkańcy się utożsamiali.

Dom, miasto, kraj - te wybrane, ulubione miejsca, to wybrane przestrzenie, im przestrzeń większa, tym miejsc naszych ich w niej mniej, a i w domu jedne lubimy bardziej, inne mniej. Mówimy: kocham moje miasto, mój kraj, ale to tylko pewne określone ich fragmenty: utożsamiamy się z nielicznymi: przestrzeniami, jak i z ludźmi³.

Emocje towarzyszące ocenie jakości wybranych do badań osiedli nie stanowiły ułatwienia w pozyskaniu obiektywnych wyników analiz. Wartością projektu była jednak nie tylko metoda badań o charakterze interdyscyplinarnym czy fakt udziału samych mieszkańców na różnych etapach realizacji projektu, ale sama współpraca ekspertów i praktyków różnych jednostek naukowych czy samorządu. Jej efektem jest publikacja w formie książki naukowej Diagnoza funkcjonalno-przestrzenna osiedli: Olsza Il i Ugorek, wyróżniona nagrodą rektora w 2015 roku.

\section{PRZYPISY}

1 Ch. Montgomery, Miasto szczęśliwe. Jak zmieniać nasze życie, zmieniajq̨c nasze miasta, Wysoki Zamek, Kraków 2015, s. 152.

2 Prof. dr hab. inż. arch. Grażyna Schneider-Skalska, dr hab. inż. arch. Justyna Kobylarczyk, prof. PK, dr inż. arch. Patrycja Haupt, dr inż. arch. Wojciech Sumlet, mgr inż. arch. Paweł Tor, dr inż. arch. Kinga Racoń-Leja oraz przedstawiciele Studenckiego Koła Naukowego Projektowania Zrównoważonego.

3 J.A. Włodarczyk, Drogi, ścieżki do architektury, Wyższa Szkoła Techniczna w Katowicach, Katowice 2010, s. 121.

\section{BIBLIOGRAFIA}

Włodarczyk J.A., Drogi, ścieżki do architektury, Wyższa Szkoła Techniczna w Katowicach, Katowice 2010.

Kobylarczyk J., Schneider-Skalska G., Haupt P., Racoń-Leja K., Sumlet W., Tor P., Studenckie Koło Naukowe Projektowania Zrównoważonego, Diagnoza funkcjonalno-przestrzenna osiedli: Olsza II i Ugorek, Politechnika Krakowska, Kraków 2014. 
Kobylarczyk J., Ocena jakości środowiska mieszkaniowego w wybranych miastach województwa podkarpackiego w okresie transformacji, w pierwszej dekadzie XXI wieku, Wydawnictwo Politechniki Krakowskiej, Kraków 2007.

Kobylarczyk J., Paprzyca K., Miejsca, nie-miejsca, Marca Auge, Wydawnictwo Politechniki Krakowskiej, Kraków 2016.

Schneider-Skalska G., Kształtowanie zdrowego środowiska mieszkaniowego. Wybrane przykłady, Wydawnictwo Politechniki Krakowskiej, Kraków 2004.

Montgomery Ch., Miasto szczęśliwe. Jak zmieniać nasze życie, zmieniajq̨ nasze miasta, Wysoki Zamek, Kraków 2015. 